\title{
TOKSISITAS AKUT DAN LETHAL DOSIS (LD50) EKSTRAK ETANOL UWI BANGGAI UNGU (Dioscorea alata L.) PADA TIKUS PUTIH (Rattus norvegicus)
}

\section{(ACUTE TOXICITY AND THE LETHAL DOSE 50 OF PURPLE YAM ETHANOL EXTRACT (Dioscorea alata L.) IN WHITE RAT (Rattus norvegicus))}

\author{
CORRY STEPHANIE SULASTRA ${ }^{1 \bullet *}$, KHILDAH KHAERATI $^{1}$, IHWAN $^{1}$ \\ ${ }^{1}$ Jurusan Farmasi, FMIPA, Universitas Tadulako, Palu
}

\begin{abstract}
Abstrak: Penelitian ini merupakan penelitian eksperimental murni dengan tujuan untuk mengetahui gejala toksisitas akut dan lethal dose 50 ekstrak etanol uwi Banggai ungu (Dioscorea alata L.) terhadap tikus putih (Rattus norvegicus). Penelitian ini menggunakan 20 ekor tikus yang dibagi menjadi empat kelompok dan diberikan dosis bertingkat yaitu $1 \mathrm{~g} / \mathrm{kgBB}, 2 \mathrm{~g} / \mathrm{kgBB}, 4 \mathrm{~g} / \mathrm{kgBB}$, dan $8 \mathrm{~g} / \mathrm{kgBB}$ ekstrak etanol uwi Banggai ungu dengan sekali pemberian secara oral kemudian diamati gejala ketoksikan dan jumlah kematian pada tiap hewan uji setelah 24 jam, selanjutnya dilakukan pengamatan bobot badan selama 14 hari tanpa diberikan perlakuan. Hasil penelitian menunjukkan $\mathrm{LD}_{50}$ ekstrak etanol uwi Banggai ungu (Dioscorea alata L.) adalah semu atau bukan $\mathrm{LD}_{50}$ yang sesungguhnya yaitu $>8 \mathrm{~g} / \mathrm{kgBB}$ dan masuk dalam kategori praktis tidak toksik $(5-15 \mathrm{~g} / \mathrm{kgBB})$. Gejala klinis yang teramati pada tikus yaitu menurunnya aktivitas motorik pada dosis tertinggi dan frekuensi grooming yang meningkat seiring dengan peningkatan dosis.
\end{abstract}

Kata Kunci: Dioscorea alata L., Lethal Dose 50, Toksisitas akut.

Abstract: This research is a pure experimental research with the aim to know the symptoms of acute toxicity and the lethal dose 50 of purple yam ethanol extract (Dioscorea alata L.) in white rat (Rattus norvegicus). This research used 20 rats were divided into four groups and given multilevel doses of $1 \mathrm{~g} / \mathrm{kgBW}, 2 \mathrm{~g} / \mathrm{kgBW}, 4$ $\mathrm{g} / \mathrm{kgBW}$, and $8 \mathrm{~g} / \mathrm{kgBW}$ of purple yam ethanol extract with single exposure then observed the symptoms of toxicity and the number of deaths in each animal after 24 hours, then performed the observation of body weight for 14 days without being given treatment. The results showed that $\mathrm{LD}_{50}$ of purple yam ethanol extract (Dioscorea alata $\mathrm{L}$.) is pseudo or not the real $\mathrm{LD}_{50}>8 \mathrm{~g} / \mathrm{kgBW}$ and included in the category of practically not toxic $(5-15 \mathrm{~g} / \mathrm{kgBW})$. Clinical symptoms observed in rats are decreased motor activity at the highest dose and frequency of grooming that increase with increasing dose.

Keywords: Acute Toxicity, Dioscorea alata L., Lethal Dose 50.

\section{PENDAHULUAN}

Uwi adalah tanaman yang penting dibanyak negara tropis, yang sebagian spesiesnya dibudidayakan untuk pangan dan obat-obatan (Huang et al., 2006; Li et al., 2011). Penggunaan obat tradisional dalam upaya mempertahankan kesehatan masyarakat telah lama kita ketahui. Bahkan sampai saat ini pun menurut perkiraan badan kesehatan dunia (WHO), $80 \%$ penduduk dunia masih menggantungkan dirinya pada pengobatan tradisional, salah satunya yaitu uwi Banggai. Uwi Banggai dimanfaatkan sebagai obat tradisional berdasarkan pada pengalaman empiris yang diturunkan secara turun-temurun. Dalam penggunaannya sebagai obat tradisional, perlu diketahui keamanannya agar tidak menimbulkan efek berbahaya yang tidak diinginkan.

Namun, saat ini belum ada data yang mendukung informasi keamanan mengenai uwi
Banggai. Oleh sebab itu perlu dilakukan pengujian lebih lanjut pada hewan uji untuk melihat ada tidaknya efek toksik untuk menjamin keamanan penggunaannya. Hasil dari penelitian yang dilakukan diharapkan dapat memberikan informasi terkait $\mathrm{LD}_{50}$ dan penggunaan dosis yang tepat serta dapat mengenali tanda-tanda toksik yang terjadi. Uji toksisitas akut merupakan salah satu uji praklinis, yaitu senyawa kimia diujikan terhadap hewan percobaan sebelum dicobakan pada manusia (Anonim, 2008).

Uji toksisitas akut merupakan cara untuk mendeteksi efek toksik yang muncul dalam waktu singkat setelah pemberian suatu zat dalam dosis tunggal atau dosis berulang yang diberikan dalam waktu tidak lebih dari 24 jam (BPOM, 2014).

Untuk menyatakan toksisitas akut umumnya dipakai nilai $\mathrm{LD}_{50}$. $\mathrm{LD}_{50}$ adalah dosis yang secara statistik dapat membunuh 50\% dari hewan percobaan. $\mathrm{LD}_{50}$ ditentukan dengan memberikan

• email korespondensi: stephaniecorry01@yahoo.com 
obat dalam dosis yang bervariasi (bertingkat) kepada sekelompok hewan percobaan dan setiap hewan diberikan dosis tunggal (Anonim, 2008).

\section{METODE PENELITIAN}

Bahan - bahan yang digunakan dalam penelitian ini adalah ekstrak etanol uwi Banggai ungu (Dioscorea alata L.), asam pikrat, Na CMC, kertas saring, tali godam, etanol, kapas, aluminium foil, tissue, jarum suntik, makanan tikus dan minuman tikus.

Ekstraksi Sokletasi. Pembuatan ekstrak etanol uwi Banggai ungu (Dioscorea alata L.) dilakukan dengan cara ekstraksi secara sokletasi yaitu dengan melakukan penyerbukkan terhadap simplisia kering uwi Banggai ungu (Dioscorea alata L.) yang telah dikeringkan terlebih dahulu, lalu diayak dengan menggunakan ayakan yang berukuran nomor mesh 100. Serbuk simplisia uwi Banggai ungu dimasukkan ke dalam slongsong, lalu diekstraksi dengan menggunakan pelarut etanol $96 \%$ sebanyak 4 liter. Ekstraksi dihentikan jika terlihat pelarut pada pipa kapiler soklet telah jernih. Ekstrak cair yang diperoleh ditampung lalu dipekatkan dengan menggunakan rotary evaporator dengan kecepatan $90 \mathrm{rpm}$ dengan suhu $57^{\circ} \mathrm{C}$ hingga diperoleh ektrak kental.

Uji Toksisitas. Pada penelitian ini, 20 ekor tikus putih galur wistar dibagi dalam 4 kelompok perlakuan yang masing-masing terdiri dari 5 ekor tikus putih yang ditentukan secara acak. Kelompok Perlakuan 1: diberi 200mg/200 gBB ekstrak etanol Uwi Banggai ungu.

Kelompok Perlakuan 2: diberi 400mg/200 gBB ekstrak etanol Uwi Banggai ungu.

Kelompok Perlakuan 3: diberi 800mg/200 gBB ekstrak etanol Uwi Banggai ungu.

Kelompok Perlakuan 4: diberi 1600mg/200 gBB ekstrak etanol Uwi Banggai ungu. Pemberian ekstrak etanol Uwi Banggai ungu (Dioscorea alata L.) pada tikus putih dilakukan menggunakan sonde dengan dosis tunggal.

Analisis Data. Perhitungan $\mathrm{LD}_{50}$ digunakan metode Thomson dan Weil. Perhitungan ini dilakukan menggunakan nilai r-values yaitu : Rumus yang digunakan yaitu:

$$
\log L_{50}=\log D+d(f+1)-2 d . d f
$$

Keterangan:

$\mathrm{D}=$ Dosis terkecil yang digunakan

$\mathrm{d}=$ logaritma kelipatan

$\mathrm{F} \quad$ = faktor yang diperoleh dari tabel
Data diperoleh dari jumlah hewan uji yang mati alam 24 jam pada setiap seri konsentrasi dosis dan dianalisis dengan menggunakan perhitungan Thomson dan Weil.

\section{HASIL DAN PEMBAHASAN}

1. Hasil Ekstraksi

Hasil proses ekstraksi uwi Banggai ungu menggunakan etanol $96 \%$ diperoleh ekstrak sebanyak 82,14 gram dengan hasil rendemen yaitu $6,43 \%$.

2. Hasil Skrining Fitokimia

Hasil skrining fitokimia disajikan pada Tabel 1 berikut :

Tabel 1. Hasil Skrining Fitokimia

\begin{tabular}{ccc}
\hline No. & $\begin{array}{c}\text { Golongan } \\
\text { Senyawa }\end{array}$ & $\begin{array}{c}\text { Hasil } \\
\text { Identifikasi }\end{array}$ \\
\hline 1. & Alkaloid & + \\
2. & Flavonoid & + \\
3. & Saponin & + \\
4. & Tanin & + \\
5. & Steroid/Triterpenoid & + \\
\hline
\end{tabular}

Keterangan :

$+=$ Ekstrak bereaksi positif

- $\quad=$ Ekstrak bereaksi negatif

3. Hasil Uji Toksisitas

Data dari uji toksisitas ekstrak etanol uwi Banggai ungu pada tikus putih (Rattus norvegicus) disajikan dalam Tabel 2.

Tabel 2. Jumlah kematian

\begin{tabular}{ccccc}
\hline No. & Kelompok & $\begin{array}{c}\text { Jumlah } \\
\text { Tikus }\end{array}$ & $\begin{array}{c}\text { Dosis } \\
\text { Ekstrak } \\
\text { (mg/200 } \\
\text { gBB) }\end{array}$ & $\begin{array}{c}\text { Jumlah } \\
\text { Kematian }\end{array}$ \\
\hline 1. & I & 5 ekor & 200 & 0 \\
2. & II & 5 ekor & 400 & 0 \\
3. & III & 5 ekor & 800 & 0 \\
4. & IV & 5 ekor & 1600 & 0 \\
\hline
\end{tabular}

Penelitian uji toksisitas akut ini dilakukan dengan melihat gejala klinis dan efek toksik terhadap ekstrak etanol uwi Banggai ungu (Dioscorea alata L.) yang dapat dilihat dari nilai $\mathrm{LD}_{50}$. Uji toksisitas dengan metode Thomson dan Weil merupakan metode yang sering digunakan karena tidak memerlukan hewan percobaan yang cukup banyak dan memiliki tingkat keakuratan yang tinggi (Supriyono, 2007).

Penelitian ini dilakukan dengan menggunakan 20 ekor tikus putih betina yang 
berumur 2-3 bulan dengan berat badan $150-250$ gram. Sebelumnya telah dilakukan aklimatisasi selama 7 hari yang bertujuan agar hewan uji terbiasa dengan tempat tinggal yang baru dan tidak stres. Hewan uji dibagi menjadi 4 kelompok dengan masing - masing kelompok terdiri dari 5 ekor tikus putih betina yang diberi ekstrak etanol uwi Banggai ungu (Dioscorea alata L.) dengan dosis bertingkat. Dosis yang digunakan yaitu $200 \mathrm{mg} / 200 \mathrm{~g} \mathrm{BB}, 400$ $\mathrm{mg} / 200 \mathrm{~g} \mathrm{BB}, 800 \mathrm{mg} / 200 \mathrm{~g} \mathrm{BB}$, dan $1600 \mathrm{mg} /$ $200 \mathrm{~g} \mathrm{BB}$.

Uwi Banggai ungu yang digunakan adalah bagian umbinya. Pembuatan ekstrak uwi Banggai ungu dilakukan dengan menggunakan metode sokletasi. Sebelum disokletasi, uwi Banggai ungu dikeringkan menggunakan oven dengan suhu $55^{\circ} \mathrm{C}$ selama 2 x 24 jam. Cairan penyari yang digunakan dalam proses sokletasi adalah etanol $96 \%$ Digunakannya etanol sebagai cairan penyari karena etanol relatif lebih aman dibandingkan cairan penyari lainnya, dapat bercampur dengan air dalam segala perbandingan, dan dalam proses pemisahan etanol juga mudah menguap sehingga mudah saat hendak dipisahkan dengan ekstrak. Selain itu, etanol yang bersifat semi polar diharapkan dapat menarik senyawa yang bersifat polar dan non polar pada uwi Banggai. Sedangkan konsentrasi etanol yang digunakan yaitu 96\%, karena simplisia yang digunakan adalah tanaman kering yang telah disimpan dan dikeringkan sehingga telah sedikit menyerap air dari udara (Nurfaat, 2016).

Setelah disokletasi, ekstrak cair lalu dipekatkan dengan menggunakan rotary evaporator. Ekstrak kental yang didapatkan yaitu 82,14 gram dengan persen rendemen yaitu $6,43 \%$. Kemudian, dilakukan skrining fitokimia yang bertujuan untuk mengetahui golongan senyawa kimia yang terkandung di dalam uwi Banggai ungu. Dari pengujian yang dilakukan terhadap ekstrak etanol uwi Banggai ungu menunjukkan bahwa ekstrak tersebut mengandung alkaloid, flavonoid, saponin, tannin, dan steroid atau triterpenoid.

Sebelum diberikan perlakuan, hewan uji dipuasakan selama 14 - 18 jam, tetapi air minum masih dapat diberikan secukupnya (BPOM, 2014). Setelah hewan uji diberikan ekstrak etanol uwi Banggai ungu sesuai dengan tingkatan dosis yang telah ditentukan, dilakukan pengamatan gejala klinis dan efek toksik selama 6 jam dan 24 jam setelah pemberian serta dilanjutkan dengan pengamatan berat badan hewan uji selama 14 hari.

Terdapat beberapa parameter yang dilihat dalam pengamatan gejala klinis dan efek toksik pada hewan uji, yaitu parameter aktivitas motorik, straub, piloereksi, ptosis, midriasis, diuresis, defekasi, salivasi, dan grooming.
Dapat dilihat bahwa gejala klinis dan efek toksik yang teramati pada tikus yaitu menurunnya aktivitas motorik pada dosis tertinggi dan frekuensi grooming yang meningkat seiring dengan peningkatan dosis. Gejala klinis dan efek toksik paling banyak terlihat pada kelompok keempat yang diberikan ekstrak etanol uwi Banggai ungu sebanyak $1600 \mathrm{mg} / 200 \mathrm{~g}$ BB. Grooming terjadi karena ekstrak uwi Banggai memiliki kandungan alkaloid yang mampu menghambat kerja pada sistem saraf (Aseptianova, Wijayanti, 2017). Gejala klinis dan efek toksik tersebut meningkat frekuensinya pada hari pertama pemberian ekstrak. Setelah 24 jam pemberian ekstrak, gejala klinis dan efek toksik yang terlihat mulai menurun. Perubahan tersebut, mulai hilang pada jam keempat sampai jam kelima setelah pemberian ekstrak etanol uwi Banggai ungu.

Hasil pengamatan nilai $\mathrm{LD}_{50}$ pada tikus yang telah diberikan ekstrak etanol uwi Banggai ungu menunjukkan adanya gejala-gejala klinis toksisitas namun tidak terdapat angka kematian pada keempat tingkatan dosis yang telah diberikan. Dengan tidak adanya kematian hewan uji, menunjukkan bahwa tidak didapatkannya faktor $\mathrm{f}$ yaitu faktor yang diperoleh dari tabel Thomson dan Weil, sehingga nilai $\mathrm{LD}_{50}$ tidak dapat dihitung. Hal ini sesuai dengan kriteria uji toksisitas akut yang dilakukan untuk menilai $\mathrm{LD}_{50}$ bahwa berdasarkan kesepakatan yang diambil para ahli, jika dosis maksimal yang diberikan tidak menimbulkan kematian hewan uji, maka $\mathrm{LD}_{50}$ dinyatakan dengan $\mathrm{LD}_{50}$ semu atau bukan $\mathrm{LD}_{50}$ yang sesungguhnya (Loomis, 1978). Bila hingga dosis $5000 \mathrm{mg} / \mathrm{kgBB}$ tidak menimbulkan kematian, maka uji tidak perlu dilanjutkan dengan menggunakan dosis bahan uji yang lebih tinggi (BPOM, 2014). Dari hasil pengujian tersebut, maka nilai $\mathrm{LD}_{50}$ semu $>8$ $\mathrm{g} / \mathrm{kgBB}$ dan ekstrak etanol uwi Banggai ungu masuk dalam kategori praktis tidak toksik (5-15 $\mathrm{g} / \mathrm{kgBB}$ ), karena dosis tertinggi yang diberikan yaitu $1600 \mathrm{mg} / 200 \mathrm{~g} \mathrm{BB}$ atau setara dengan 8 g/kgBB. Menurut (Armansyah, dkk., 2016), pada uji toksisitas akut yang telah dilakukan tidak menimbulkan kematian hewan uji setelah pemberian dosis tunggal bahan uji, sehingga untuk menentukan nilai $\mathrm{LD}_{50}$ dari ekstrak tersebut, digunakan dosis tertinggi yang diberikan kepada hewan uji.

Data dari hasil pengujian toksisitas akut yang diperoleh disajikan dalam bentuk grafik. Grafik hubungan mortalitas tikus dengan log konsentrasi ekstrak etanol uwi Banggai ungu disajikan dalam Grafik 1. 


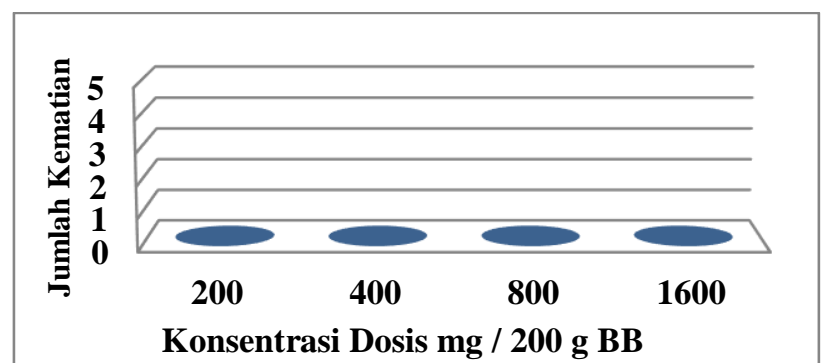

Grafik 1. Hubungan mortalitas dengan log konsentrasi

Dalam uji toksitas akut, penentuan $\mathrm{LD}_{50}$ dilakukan dengan cara menghitung jumlah kematian hewan uji yang terjadi setelah 24 jam pertama sesudah pemberian dosis tunggal bahan yang akan diujikan. Namun, tidak didapatkan kematian hewan uji pada pengujian ini. Pengujian $\mathrm{LD}_{50}$ bukan satu-satunya pengujian yang digunakan menilai toksisitas suatu bahan obat atau zat. Pengujian lain yang perlu dilakukan adalah pengujian lanjutan untuk memperkuat analisa keracunan dan toksisitas suatu zat atau bahan obat (Supriyono, 2007).

Dalam pengujian ini, juga dilakukan pengamatan berat badan terhadap hewan uji yang dilakukan selama 14 hari. Hal tersebut dilakukan untuk melihat pengaruh pemberian ekstrak terhadap perubahan berat badan yang terjadi selama 14 hari (Nurfaat, 2016).

Pengamatan berat badan hewan uji dapat dilihat pada Grafik 2.

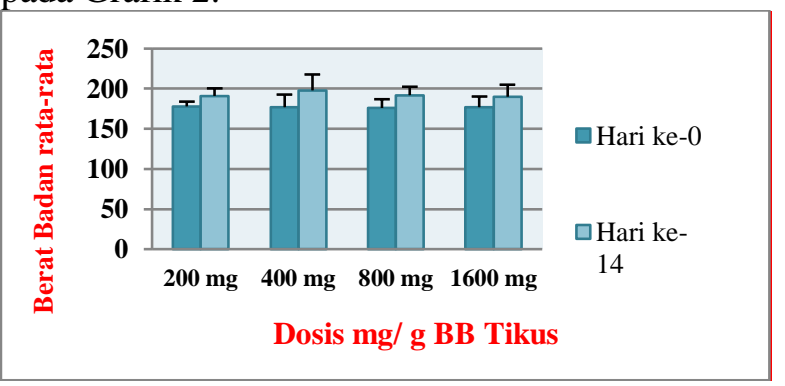

Grafik 2. Berat badan rata-rata tikus pada hari ke-0 dan hari ke-1

Dari nilai berat badan rata-rata, dapat dilihat bahwa terjadi peningkatan berat badan hewan uji pada tiap kelompok. Dari nilai rata-rata berat badan yang diperoleh, pada kelompok pertama yang diberikan ekstrak etanol uwi Banggai ungu $200 \mathrm{mg} /$ $200 \mathrm{~g} \mathrm{BB}$, mengalami peningkatan berat badan yang terhitung dari hari ke-0 yaitu 178,4 gram dan hari ke-14 yaitu 191,8 gram. Pada kelompok kedua yang diberikan ekstrak etanol uwi Banggai ungu $400 \mathrm{mg} /$ $200 \mathrm{~g} \mathrm{BB}$, mengalami peningkatan berat badan yang terhitung dari hari ke-0 yaitu 177,9 gram dan hari ke-14 yaitu 198,4 gram. Pada kelompok ketiga yang diberikan ekstrak etanol uwi Banggai ungu $800 \mathrm{mg} /$ $200 \mathrm{~g} \mathrm{BB}$, mengalami hal yang sama yaitu peningkatan berat badan yang terhitung dari hari ke-
0 yaitu 176,5 gram dan hari ke-14 yaitu 192,5 gram. Dan pada kelompok keempat yang diberikan ekstrak etanol uwi Banggai ungu $1600 \mathrm{mg} / 200 \mathrm{~g}$ $\mathrm{BB}$, juga mengalami peningkatan berat badan yang terhitung dari hari ke-0 yaitu 177,8 gram dan hari ke-14 yaitu 190,7 gram.

Dilakukan pengamatan berat badan hewan uji selama 14 hari yaitu untuk mengetahui kondisi hewan uji setelah pemberian ekstrak etanol uwi Banggai ungu. Kondisi yang mengindikasikan hewan mengalami sakit dan / atau derita umumnya saat berat badan yang telah menurun lebih dari $20 \%$ atau berat badan yang telah menurun lebih dari $25 \%$ selama periode 7 hari atau lebih. Biasanya, disertai dengan penurunan atau tidaknya konsumsi makanan. Hewan uji mengalami fluktuatif perubahan berat badan menandakan adanya sakit atau derita setelah pemberian ekstrak (Nurfaat, 2016). Tetapi, pada pengamatan yang telah dilakukan selama 14 hari, tidak didapatkannya hewan uji yang mengalami sakit atau derita setelah pemberian ekstrak, hal ini ditandai dengan peningkatan berat badan hewan uji. Ekstrak etanol uwi Banggai ungu aman sehingga tidak memberikan sakit atau derita yang berarti terhadap berat badan hewan uji. Hal tersebut menyatakan bahwa, tidak adanya hubungan antara gejala klinis dan efek toksik pada berat badan tikus karena selama 14 hari pengamatan terhadap berat badan tikus tidak terjadi penuruan berat badan.

\section{SIMPULAN}

Gejala klinis ekstrak etanol uwi Banggai ungu (Dioscorea alata L.) yang teramati pada tikus, yaitu menurunnya aktivitas motorik pada dosis tertinggi dan frekuensi grooming yang meningkat seiring dengan peningkatan dosis. $\mathrm{LD}_{50}$ ekstrak etanol uwi Banggai ungu (Dioscorea alata L.) adalah semu $>8 \mathrm{~g} / \mathrm{kgBB}$ dan masuk dalam kategori praktis tidak toksik (5-15 g/kgBB), karena dosis tertinggi yang diberikan yaitu $1600 \mathrm{mg} / 200 \mathrm{~g} \mathrm{BB}$ atau setara dengan $8 \mathrm{~g} / \mathrm{kgBB}$.

\section{DAFTAR PUSTAKA}

Anonim. (2008). Kumpulan Kuliah Farmakologi. Jakarta: Fakultas Kedokteran Universitas Sriwijaya.

Armansyah, T., dkk., (2016). Uji Toksisitas Akut Ekstrak Etanol Daun Malaka (Phyllantus emblica) Terhadap Mencit (Mus musculus). Banda Aceh: Fakultas Kedokteran Universitas Syiah Kuala. 
Aseptianova, Wijayanti, N. N. (2017). Efektifitas Pemanfaatan Tanaman Sebagai Insektisida Elektrik Untuk Mengendalikan Nyamuk Penular Penyakit DBD. Universitas Muhammadiyah Palembang, 3(2), 10-19.

BPOM. (2014). Pedoman Uji Toksisitas Nonklinik Secara In Vivo. Badan Pengawas Obat dan Makanan Republik Indonesia.

Huang CC, Lin MC, and Wang CCR. (2006). Changes in morphological, thermal and pasting properties of yam (Dioscorea alata) starch during growth. Carbohydrate Poly 64: 524531.

Loomis, T,A., (1987). Essential of Toxicology. 3rd ed. Philadelpia.
Nurfaat, D. L. (2016). Uji Toksisitas Akut Ekstrak Etanol Benalu Mangga (Dendrophthoe petandra) Terhadap Mencit Swiss Webster. Indonesian Journal of Pharmaceutical Science and Technology, 3(2), 53-65.

Rohyani, I.C., Aryanti, E., \& Suripto. (2015). Kandungan Fitokimia Beberapa Jenis Tumbuhan Lokal Yang Sering Dimanfaatkan Sebagai Bahan Baku Obat di Pulau Lombok. Nusa Tenggara Barat: Universitas Mataram.

Supriyono. (2007). Pengujian Lethal dosis (ld50) Ekstrak Etanol Biji Buah Duku ( Lansium domesticum Corr) pada Mencit (Mus musculus), 1-4. Institut Pertanian Bogor. 